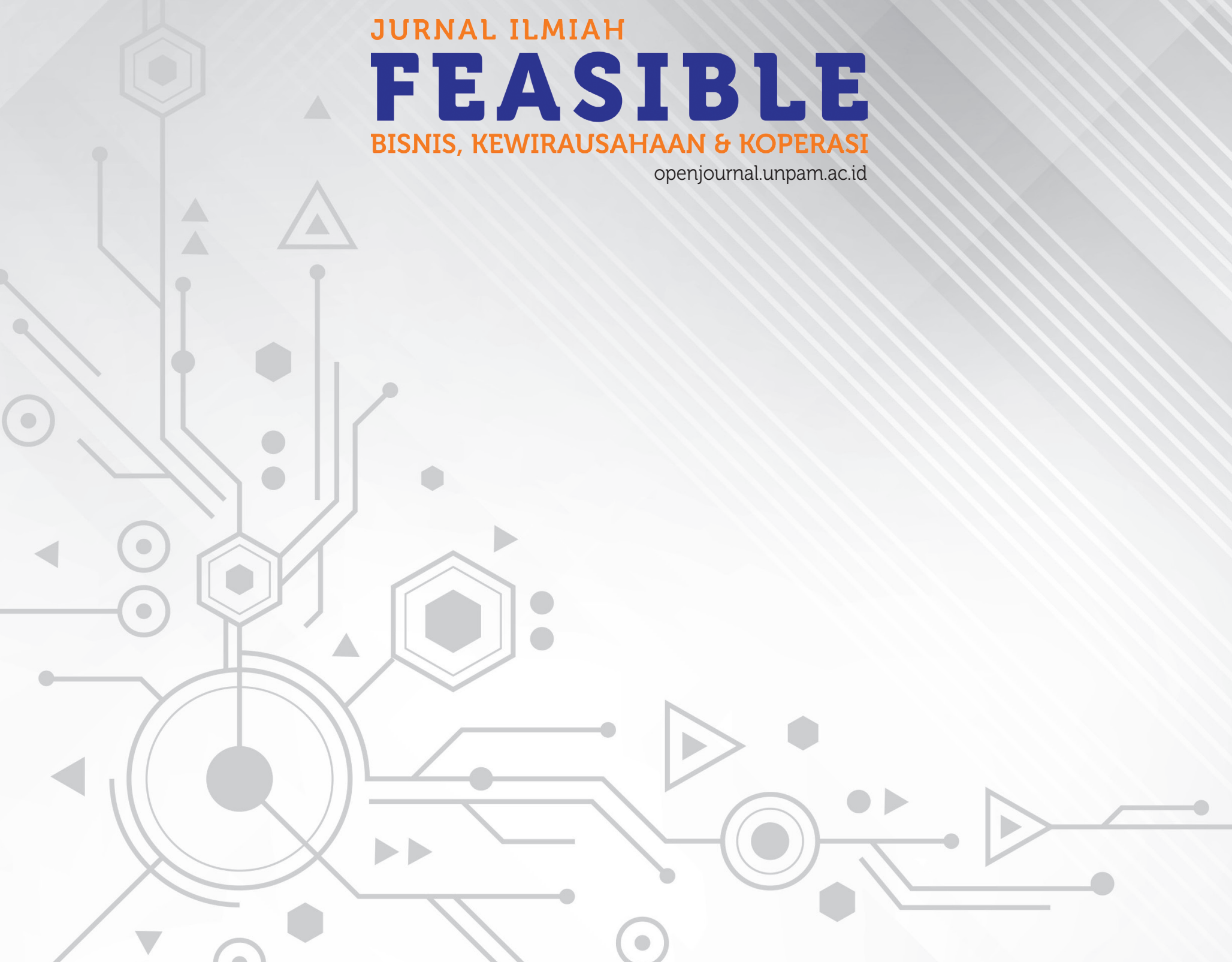




\title{
ANALISIS KINERJA KEUANGAN PERUSAHAAN MANUFAKTUR (Sebuah Studi Empiris Pada Perusahaan Manufaktur Industri Logam Go Public di BEI) Periode 2012-2016
}

\author{
H. Buchari E.Satiaputra \& Herry Suherman \\ Universitas Pamulang \\ email: bucharisatiaputra@gmail.com; herryman773@gmail.com
}

\begin{abstract}
Abstrak
Periode 5 tahun terakhir, merupakan waktu yang cukup sulit yang dihadapi oleh perusahaan manufaktur di Indonesia, masuknya era globalisasi, persaingan pasar bebas, fluktuasi nilai tukar rupiah terhadap mata uang asing dan inflasi yang cukup tinggi. Menurut pernyataan Bank Indonesia pada kuartal kedua 2015 pelemahan rupiah cukup dalam (overshoot) dan telah di bawah nilai fundamental (undervalued). Pada 2015, kesulitan yang dihadapi oleh perusahaan manufaktur cukup serius. Tujuan dari penelitian ingin menganalisis kinerja keuangan perusahaan manufaktur dengan menggunakan motode Almant Z-Score yang telah dimodifikasi tahun 1997 yang meliputi WCTA, RETA, ROI, BVETL dan TATO sebagai variabel independen memiliki hubungan yang positif terhadap Z-Score sebagai variabel dependen yang mewakili kesulitan keuangan atau kebangkrutan perusahaan akibat inflasi dan fluktuasi rupiah yang berkepanjangan dan tidak ada kepastian. Pemilihan sampel berdasarkan purposive sampling. Total sampel semua perusahaan manufaktur yang terdaftar di Bursa Efek Indonesia. Analisis digunakan adalah metode Altman Z-Score revisi 1997 merupakan analisis regresi berganda, analisis korelasi (PPM), asumsi klasik, uji hipotesis terdiri dari uji koefisien determinasi, uji-F dan uji-t. Pengujian digunakan program EVIEWS-7.
\end{abstract}

Kata kunci: WCTA, RETA, ROI, BVETL, TATO dan Z-Score

\begin{abstract}
In the last 5-year period, were pretty tough times faced by the manufacturing companies in Indonesia, the entry of the era of globalization, free market competition, in which the fluctuation of the rupiah against foreign currencies and inflation has been quite high. According to Indonesian Bank's statement in the second quarter 2015 the weakening rupiah deep enough (overshoot) and has been below the fundamental value (undervalued). In 2015, difficulties faced by manufacturing companies to conduct serious enough. The purpose of the study is to analyze with using Almant method which has been modified in 1997 whether the company's key financial performance namely WCTA, RETA, ROI, BVETL and TATO hereinafter referred to as the independent variables possess a positive relationship on $Z$-Score as the dependent variable as representative to financial distress or bankrupt as a consequence of prolonged inflation and rupiah fluctuations and uncertainty. The selection of samples based on purposive sampling. The total samples are all of manufacturing companies which listed on the Indonesian Stock Exchange. The methods Almant-Z-Score revision 1997analyze should been used in this study that multiple regression analysis, correlation analysis (PPM), classic assumptions, hypothesis test using the adjusted of the determination coefficient, the F-test and t-test. To analyzed the methods should be done with the EVIEWS program.
\end{abstract}

Keywords: WCTA, RETA, ROI, BVETL, TATO and Z-Score. 


\section{PENDAHULUAN \\ Latar Belakang}

Kurs rupiah terus anjlok sampai tahun 2016 rata-rata kurs terdevaluasi rupiah di atas Rp14.000 per dolar Amerika dan pada semester dua tahun 2016 rupiah menembus angka di atas Rp14.00o per dolar Amerika, akibatnya pertumbuhan ekonominya negatif dan inflasi membumbung tinggi, Krisis keuangan yang melanda Indonesia akibat melemahnya nilai tukar rupiah dan tidak hanya berakibat pada krisis keuangan, ekspor cukup memperhatinkan membuat sektor riil sudah diambang kritis.

Pada triwulan ke II 2015, menurut Bank Indonesia rupiah dicatat pelemahan cukup dalam (overshoot) dan telah di bawah nilai fundamental (undervalued). Dengan devaluasi rupiah yang cukup tajam terhadap mata uang asing di pasar valuta asing, melemahnya rupiah di pertengahan tahun 2015 menciptakan ketidakpastian yang sangat mempengaruhi dunia usaha nasional, khususnya disektor riil.

Altman dalam Weston Copeland (jilid 1, 2010:288-290), Altman (1968) mengunakan analisis diskriminan dengan menyusun suatu model untuk menguji manfaat rasio keuangan untuk mengetahui bagaimana kesulitan keuangan (financial distress) suatu perusahaan serta memprediksi kebangkrutan perusahaan. Dalam penelitiannya diperoleh hasil bahwa rasio keuangan likuiditas, profitabilitas dan aktivitas bermanfaat dalam memprediksi kebangkrutan. Altman menemukan lima rasio keuangan yang dapat digunakan untuk mendeteksi kesehatan kinerja keuangan perusahaan. Kelima rasio tersebut antara lain:

1. Rasio Modal Kerja terhadap Total Aktiva.

2. Rasio Labah Ditahan terhadap Total Aktiva.

3. Rasio Laba bersih operasi terhadap Total Aktiva.

4. Rasio Nilai buku dari ekuitas terhadap Total Liabilitas.

5. Rasio Penjualan terhadap Total Aktiva.

Kelima rasio inilah yang akan digunakan dalam menganalisa laporan keuangan dari suatu perusahaan untuk kemudian mendeteksi kesehatan keuangan perusahaan tersebut. Dengan menggunakan kelima rasio tersebut kemudian dicoba diterapkan untuk menganalisis laporan keuangan dalam bentuk diskriminan. Hasil dari perhitungan Altman lebih dikenaldengan sebutanZ-Score.Z-Score dapat digunakan untuk menguji karakteristik unik dari kegagalan usaha dengan menentukan sejumlah variabel yang merupakan indikator efektif untuk memprediksi kesehatan kinerja keuangan perusahaan akibat fluktuasi kurs rupiah periode 2012-2016 yaitu perusahaan manufaktur yang telah terdaftar (go public) di Bursa Efek Indonesia.

Dari latar belakang yang diuraikan di atas serta melihat pada penelitian-penelitian sebelumnya, sehingga penulis tertarik untuk mengetahui bagaimana tingkat kesehatan kinerja keuangan perusahaan setelah terjadi ketidakstabilan kurs rupiah terhadap mata uang asing khususnya dolar Amerika, dan inflasi dengan peningkatan cukup signifikan dalam kurun waktu lima tahun terakhir yaitu periode tahun 2012-2016.

Dalam hal ini, penelitian difokuskan untuk melakukan analisis kinerja keuangan perusahaan manufaktur di bidang industri logam telah terdaftar (go public) di Bursa Efek Indonesia akibat pengaruh fluktuasi kurs rupiah, dengan judul Analisis Kinerja Keuangan Perusahaan Manufaktur (Sebuah Studi Empiris Pada Perusahaan Manufaktur Industri Logam Go Public Di BEI) Periode 2012-2016.

\section{Identifikasi Masalah}

Sesuai dengan latar belakang penelitian di atas maka masalah-masalah yang berkaitan dengan kinerja keuangan terindifikasi sebagai berikut:

1. Fluktuasi kurs rupiah yang cukup tajam terhadap dolar Amerika.

2. Laju inflasi tinggi.

3. Ketidakstabilan perekonomian yang berkepanjangan secara makro.

4. Pertumbuhan ekonomi yang lambat.

5. Ekspor yang lesu.

6. Devisit perdagangan luar negri.

\section{Pembatasan Masalah}

Penelitian dibatasi pada perusahaan manufaktur yang bergerak di bidang pabrik logam yang telah terdaftar atau go public di Bursa Efek Indonesia dan sebagai metode analisis yang digunakan dalam penelitian ini, sebagai berikut:

1. Menerapkan suatu model analisis diskriman dengan kombinasi berbagai rasio untuk memprediksi kinerja keuangan dari perusahaan manufaktur industri logam (metal) akibat pengaruh fluktuasi kurs Rupiah.

2. Menggunakan rasio keuangan profitabilitas, likuiditas dan aktivitas dari ke lima rasio keuangan dalam memprediksi kondisi kesehatan keuangan perusahaan manufaktur dan jasa tersebut di atas, yaitu: a. Rasio Likuiditas:

- Rasio Modal Kerja terhadap Total Aktiva 
b. Rasio Profitabilitas:

- Rasio Laba Ditahan terhadap Total Aktiva

- Laba Sebelum Bunga dan Pajak terhadap Total Aktiva

c. Rasio Aktivitas:

- Nilai buku dari ekuitas terhadap Total liabilitas

- Penjualan terhadap Total Aktiva

3. Menguji karakteristik dari variabel independen yang merupakan indikator efektif untuk memprediksi kesehatan kinerja keuangan perusahaan.

\section{Tujuan Penelitian}

Untuk mendapatkan gambaran bagaimana pengaruh fluktuasi kurs rupiah yang berkepanjangan terhadap kesehatan kinerja keuangan perusahaan manufaktur, khususnya yang bergerak di bidang industri logam (metal) yang telah terdaftar (go public) di Bursa Efek Indonesia untuk periode 2012-2016.

\section{Landasan Teori}

1. Pengertian Laporan Keuangan

Menurut Kasmir (2015:7) laporan keuangan adalah laporan yang menunjukkan kondisi keuangan perusahaan pada saat ini atau dalam suatu periode tertentu. Laporan keuangan menggambarkan pospos keuangan perusahaan yang diperoleh dalam suatu periode. Dalam praktiknya dikenal beberapa macam laporan keuangan sperti: neraca, laporan laba rugi, laporan perubahan modal, laporan kas dan laporan catatan atas laporan keuangan.

2. Analisis Laporan Keuangan

Menurut Manahan (2013:39-40), analisis keuangan yang menghasilkan informasi tentang penilaian dan keadaan keuangan korporasi, baik yang telah lampau, atau saat sekarang serta harapannya dimasa mendatang. Tujuan analisis ini adalah untuk mengindentikasi setiap kelemahan dari keadaan keuangan yang dapat menimbulkan masalah di masa akan datang, serta menentukan setiap kekuatan yang dapat menjadi suatu keunggulan korporasi. Disamping itu analisis yang dilakukan oleh pihak luar korporasi dapat digunakan untuk menentukan tingkat kredibilitas atau potensi untuk investasi.

3. Pengertian Kinerja Keuangan

Menurut Fahmi (2014:108), kinerja keuangan merupakan gambaran dari pencapaian keberhasilan perusahaan dapat diartikan sebagai hasil yang telah dicapai atas berbagai aktivitas yang telah dilakukan. Dapat dijelaskan bahwa kinerja keuangan adalah suatu analisis yang dilakukan untuk melihat sejauh mana suatu perusahaan telah melaksanakan dengan menggunakan aturan-aturan pelaksanaan keuangan secara baik dan benar. Pengertian kinerja keuangan yakni penentuan ukuran-ukuran tertentu yang dapat mengukur keberhasilan suatu organisasi atau perusahaan dalam menghasilkan laba.

4. Pengertian Rasio Keuangan

Menurut Munawir (2014:64) ratio menggambarkan suatu hubungan atau perimbangan (mathematic relationship) antara suatu jumlah tertentu dengan jumlah yang lain, dan dengan menggunakan alat analisis berupa rasio ini akan dapat menjelaskan atau memberi gambaran kepada penganalisis tentang baik atau buruknya keadaan kondisi keuangan suatu perusahaan terutama apabila angka rasio tersebut dibandingkan dengan angka rasio pembanding yang digunakan sebagai standard.

\section{Financial Distress}

Menurut Hanafi Halim (2014:261) ada beberapa indikator yang dapat menjadi prediksi kebangkrutan. Salah satu sumbernya adalah aliran kas untuk saat ini atau untuk masa mendatang. Sumber lain adalah strategi perusahaan. Analisis ini memfokuskan pada persaingan yang dihadapi oleh perusahaan, struktur biaya relatif terhadap pesaingnya, kualitas manajemen, kemampuan manajemen mengendalikan biaya, dan lainnya. Sumber lainnya adalah laporan keuangan perusahaan. Laporan keuangan ini dapat digunakan untuk memprediksi kesulitan keuangan. Sumber lainnya adalah informasi eksternal. Pada pasar keuangan yang sudah maju, lembaga penilai (rating), informasi mereka dapat digunakan untuk memprediksi adanya kesulitan keuangan (financial distress).

Salah satu studi tentang prediksi ini adalah studi yang dilakukan oleh Edward I Altman (1968) dalam Weston Copeland (jilid 1, 2010:288-291), Altman menggunakan analisis diskriminan dengan menyusun suatu model untuk memprediksi kebangkrutan perusahaan. Ia mengambil sampel dari 66 perusahaan manufaktur, setengah diantaranya mengalami kebangkrutan dari laporan keuangan, satu periode sebelum perusahaan bangkrut, Altman memperoleh 22 rasio keuangan, di mana lima diantaranya ditemukan paling berkontribusi pada model prediksi.

Altman menggunakan analisis diskriminan 
dimana fungsi diskriminan Z-Score, hasil analisa menunjukkan bahwa rasio keuangan profitabilitas, liquiditas, dan aktivitas bermanfaat dalam memprediksi kebangkrutan, modifikasi Altman Z-Score pada tahun 1997 untuk perusahaan manufaktur:

$Z=0,717 X_{1}+0,847 X_{2}+3,107 X_{3}+0,420 X_{4}$ $+0,998 \mathrm{X}_{5}$

Dengan zona diskriminan sebagai berikut:

- $\quad Z>2,90=$ zone aman

- $\mathrm{Z}$ diantara $1,23-2,9$ atau $1,23<\mathrm{Z}>2,90=$ Zone rawan

- $\mathrm{Z}<1,23$ = zone tidak aman (distress)

Di mana:

$\mathrm{X}_{1} \quad$ = Modal kerja bersih terhadap Total Aktiva

$\mathrm{X}_{2}=$ Laba ditahan terhadap Total Aktiva

$\mathrm{X}_{3}=$ Laba bersih Operasi terhadap Total Aktiva

$\mathrm{X}_{4}=$ Nilai buku ekuitas terhadapTotal kewajiban

$\mathrm{X}_{5}=$ Penjualan terhadap Total Aktiva

\section{Hasil Penelitian Terdahulu}

Ani Rahmawati dan Joko Pramono (2013) melakukan penelitian dengan judul "Penerapan Analisa Diskriminasi Altman Untuk Memprediksi Kebangkrutan Perusahaan" (Studi kasus pada Industri Makanan dan Minuman yang terdaftar di BEI) dalam Jurnal Among Makarti Vol.6 No.11, Juli 2013, penelitian untuk mengetahui akibat persaingan industri makanan dan minuman yang semakin ketat akibat meningkatnya jumlah industri-industri makanan dan minum. Sampel dipilih dengan purposive sampling dengan kriteria yang telah ditentukan, sebanyak 16 industri makanan dan minuman yang terdaftar di BEI perode 20062010. Dengan menggunakan diskriminan Altman Z-Score untuk perusahaan manufaktur: Z-Score $=0,717 \mathrm{X}_{1}+0,847 \mathrm{X}_{2}+3,107 \mathrm{X}_{3}+$ $0,42 X_{4}+0,998 X_{5}$, dan rasio keuangan yang digunakan adalah working capital to total assets, retained reaning to total assets, EBIT to total assets, book value of equity to total laibility dan sales to total assets. Hasil analisis menunjukkan 1 perusahaan dalam keadaan sehat, 11 perusahaan dalam posisi grey area (rawan) dan 4 perusahaan dalam katagori tidak sehat.

Mokhamad I.D. Nugroho dan Wisnu Mawardi (2012: 1-10), menggunakan model Altman Z-Score modifikasi tahun 1995 dalam penelitiannya "Analisis Prediksi Financial Distress Dengan Menggunakan Model Altman Z-Score Modifikasi 1995" (Studi Kasus Pada Perusahaan Manufaktur Yang Go Public di Indonesia Tahun 2008 sampai dengan Tahun 2010) dalam Diponogoro Journal of
Management Volume 1, Nomor 1, Tahun 2012, halaman 1/11. Sampel dipilih dengan purposive sampling dengan kriteriayang telah ditentukan, sebanyak 88 perusahaan manufaktur yang terdaftar di BEI perode 2008-2010. Dengan menggunakan diskriminan Altman Z-Score untuk perusahaan manufaktur: Z-Score $=$ $-0,175+0,059 X_{1}+0,846 X_{2}+3,777 X_{3}+$ $0,069 \mathrm{X}_{4}$, dan rasio keuangan yang digunakan adalah working capital to total assets, retained reaning to total assets, EBIT to total assets dan book value of equity to total laibility. Dari hasil analisis diskriminan dengan menggunakan perhitungan metode Altman Z-Score modifikasi 1995, telah diprediksi ada 10 perusahaan distress dan 78 perusahaan non-distress. Dari hasil proses menggunakan SPSS dengan rumus Z-score Altman modifikasi 1995, nilai dari level klasifikasi untuk perusahaan distress 73,3\% dan nilai kesalahan pada level 26,7\%,. Untuk level klasifikasi perusahaan non-distress $86,2 \%$, rata-rata kesalahan dan bernilai $13,8 \%$. Dari penelitian ini variabel rasio yang digunakan mempunyai dampak yang positif terhadap financial distress.

Sedangkan model Altman Z-Score (1997)= $0.717 \mathrm{X}_{1}+0,874 \mathrm{X}_{2}+3,107 \mathrm{X}_{3}+0.420 \mathrm{X}_{4}+$ $0.988 \mathrm{X}_{5}$ di mana variabel $\mathrm{X}_{1} \mathrm{X}_{2}^{3}, \mathrm{X}_{3}, \mathrm{X}_{4}$ dan $\mathrm{X}_{5}$ adalah working capital to total assets, retained earning to total assets, EBIT to total assets dan sales to total assets dan Model Springate S-Score $=1,03 \mathrm{~A}+3,07 \mathrm{~B}+0,66 \mathrm{C}+0,4 \mathrm{D}$, di mana variabel A,B,C dan D adalah working capital to total assets, net profit before interest and taxes to total asset, net profit before taxes to current liabilities dan sales to total assets. Keduanya model Altman dan model springate mampu memprediksi delisting. Penelitian ini menemukan bahwa model Altman merupakan prediktor delisting terbaik.

\section{Kerangka Pemikiran}

Kesehatan keuangan suatu perusahaan merupakan suatu indikator yang sering digunakan untuk memilih suatu investasi. Salah satu cara untuk menilai kinerja keuangan perusahaan adalah dengan melihat laporan keuangannya.

Dalam penelitian ini digunakan pendekatan metode multiple discriminant analysis dari model Altman Z-Score dalam menganalisis kesehatan keuangan suatu perusahaan dengan menggunakan penggabungan rasio-rasio keuangan, yaitu:

1. Rasio Likuiditas mengukurkemampuan perusahaan untuk memenuhi kewajibannya yang jatuh tempo.

$\mathrm{X}_{1}=$ Modal Kerja terhadap Total Aktiva 
2. Rasio Profitabiliats mengukur efektivitas manajemen berdasarkan hasil pengembalian yang dihasilkan dari penjualan dan investasi.

$\mathrm{X}_{2}=$ Laba ditahan terhadap Total Aktiva

$\mathrm{X}_{3}^{2}=$ Laba Sebelum Bunga dan Pajak terhadap Total Aktiva

3. Rasio Aktivitas mengukur perkembangan aktivitas perusahaan dalam mempergunakan sumber-sumber.

$\mathrm{X}_{4}=$ Nilai buku terhadap Total Liabilitis

$\mathrm{X}_{5}^{4}=$ Penjualan terhadap Total Aktiva

Angka-angka rasio $\mathrm{X}_{1}$ sampai dengan $\mathrm{X}_{5}$ yang dihasilkan kemudian dikalikan dengan koefisien yang diturunkan Altman. Untuk menghitung Z - Score dilakukan dengan menjumlah angka-angka kelima rasio dari persamaan fungsi diskriminan Z. Dari hasil penjumlahan diperoleh hasil berupa angka atau nilai $\mathrm{Z}$ - Score yang kemudian dapat menjelaskan tentang kemungkinan kesehatan keuangan pada sebuah perusahaan.

Nilai Z - Score ini akan menjelaskan kondisi keuangan perusahaan yang dibagi dalam beberapa tingkatan atau kategori, yaitu untuk nilai $\mathrm{Z}$ - Score lebih kecil dengan 1,22 (Z Score < 1,22), maka perusahaan mengalami kinerja keuangan tidak sehat (distress). Untuk nilai Z - Scordie antara 1,22 sampai 2,90 maka kondisi kinerja masuk zone rawan, bila lebih besar dari 2,90 ( $\mathrm{Z}$ - Score > 2,90) memberikan penilaian bahwa perusahaan memiliki kinerja keuangan yang sehat sehingga kemungkinan kebangkrutan sangat kecil terjadi.

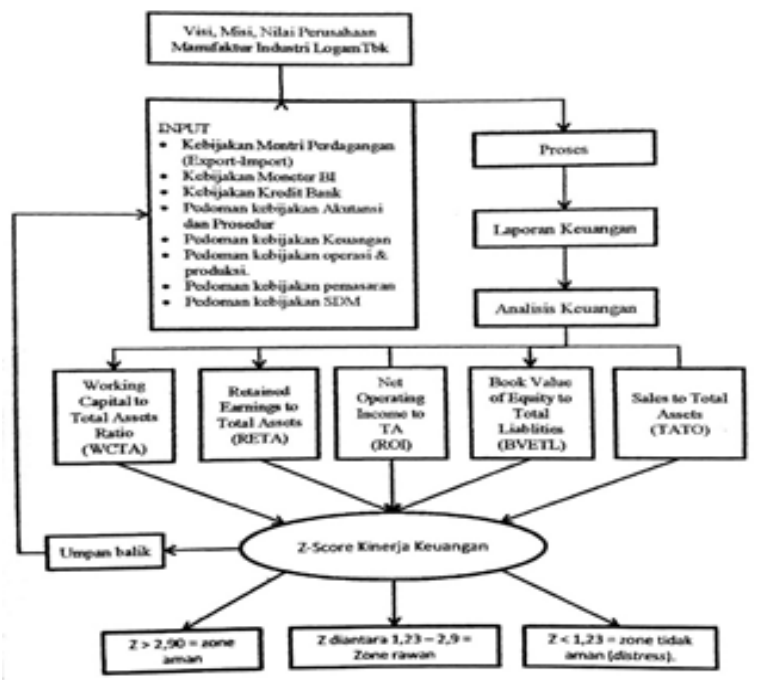

Gambar: 1.1. Kerangka Pemikiran

\section{Hipotesis Penelitian}

Hipotesis dalam penelitian adalah " Ada perbedaan kesehatan kinerja keuangan antara perusahaan yang masuk kategori tidak sehat, rawan dan sehat pada perusahaan manufaktur yang telah go public di Bursa Efek Indonesia periode tahun 2012-2016 terhadap flutuasi kurs rupiah maka dirumuskan dalam penelitian ini sebagai berikut:

$\mathrm{H}_{01}$ : Diduga terdapat pengaruh yang signifikan dari WCTA terhadap Z-Score (kinerja keuangan).

$\mathrm{H}_{\mathrm{a} 1}$ : Diduga tidak terdapat pengaruh yang signifikan dari WCTA terhadap Z-Score (kinerja keuangan).

$\mathrm{H}_{02}$ : Diduga terdapat pengaruh yang signifikan dari RETA terhadap Z-Score (kinerja keuangan).

$\mathrm{H}_{\mathrm{a} 2}$ : Diduga tidak terdapat pengaruh yang signifikan dari RETA terhadap Z-Score (kinerja keuangan).

$\mathrm{H}_{\text {оз }}$ : Diduga terdapat pengaruh yang signifikan dari ROI terhadap Z-Score (kinerja keuangan).

$\mathrm{H}_{\text {a3 }}$ : Diduga tidak terdapat pengaruh yang signifikan dari ROI terhadap Z-Score (kinerja keuangan).

$\mathrm{H}_{04}$ : Diduga terdapat pengaruh yang signifikan dari BVETL terhadap Z-Score (kinerja keuangan).

$\mathrm{H}_{\mathrm{a} 4}$ : Diduga tidak terdapat pengaruh yang signifikan dari BVETL terhadap Z-Score (kinerja keuangan).

$\mathrm{H}_{05}$ : Diduga terdapat pengaruh yang signifikan dari WCTA terhadap Z-Score (kinerja keuangan).

$\mathrm{H}_{\text {a5 }}$ : Diduga tidak terdapat pengaruh yang signifikan dari WCTA terhadap Z-Score (kinerja keuangan).

$\mathrm{H}_{\text {o6 }}$ : Diduga terdapat pengaruh yang signifikan dari variabel $\mathrm{X}_{1} \mathrm{X}_{2}, \mathrm{X}_{3}, \mathrm{X}_{4}$ dan $\mathrm{X}_{5}$ terhadap Z-Score (kinerja keuangan).

$\mathrm{H}_{\mathrm{a} 6}$ : Diduga tidak terdapat pengaruh yang signifikan dari variabel $\mathrm{X}_{1} \mathrm{X}_{2}, \mathrm{X}_{3}, \mathrm{X}_{4}$ dan $\mathrm{X}_{5}$ terhadap Z-Score (kinerja keuangan).

Variabel-variabel yang digunakan dalam penelitian

1. Variabel Dependen: Z-Score Kinerja Keuangan (zone sehat, zone rawan dan zone tidak sehat)

2. Variabel Independen (X):

$\mathrm{X}_{1}$ : Rasio modal kerja terhadap total aktiva (\%)

$\mathrm{X}_{2}$ : Rasio laba ditahan terhadap total aktiva (\%)

$\mathrm{X}_{3}$ : Rasio laba bersih Operasi terhadap total aktiva(\%)

$\mathrm{X}_{4}$ : Nilai buku modal sendiri terhadap total liabilitas (\%)

$\mathrm{X}_{5}$ : Rasio penjualan terhadap total Aktiva (kali) 


\section{METODOLOGI PENELITIAN Metode Penelitian}

Dalam penelitian ini dilakukan metode survei dengan pendekatan kuantitatif melalui analisis multipel diskriminan dan analisis korelasi (PPM) terhadap Altman Z-Score. Analisis ini akan digunakan dalam menguji pengaruh fluktuasi kurs rupiah terhadap kinerja keuangan perusahaan manufaktur di bidang industri logam untuk periode 2012-2016.

\section{Disain Penelitian}

Penelitian ini dilakukan pada perusahaan manufaktur di bidang produksi logam yang telah terdaftar di Bursa Efek Indonesia periode 2012-2016. Data penelitian terdiri dari laporan keuangan dari persuhaan tersebut yang menjadi sampel yang berhubungan dengan rasio modal kerja terhadap total aktiva $\left(\mathrm{X}_{1}\right)$, rasio laba ditahan terhadap total aktiva $\left(\mathrm{X}_{2}\right)$, rasio laba bersih Operasi terhadap total aktiva $\left(\mathrm{X}_{\mathrm{s}}\right)$, rasio nilai buku modal sendiri terhadap total liabilitas $\left(\mathrm{X}_{\mathrm{f}}\right)$, rasio penjualan terhadap total Aktiva $\left(\mathrm{X}_{5}\right)$ dan Z-Score Kinerja keuangan (Y).

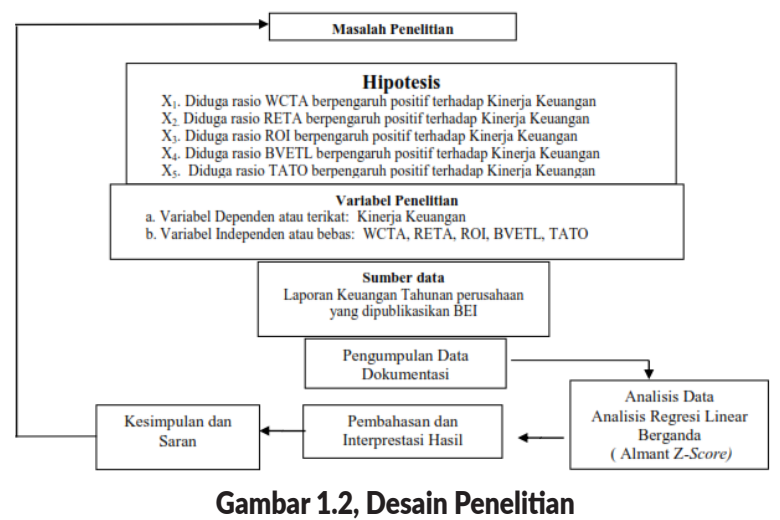

\section{Definisi Operasional Variabel}

Score (X)

Rasio Keuangan Pendekatan AltmanZ-

Variabel independen dalam penelitian ini menggunakan rasio keuangan pendekatan Altman untuk perusahaan manufaktur di bidang industri logam dan persusahaan yang go public di Bursa Efek Indonesia periode 20122016.

Dalam penelitian ini digunakan model Altman Z-Score yang telah direvisi tahun 1997 sebagai alat analisis untuk mengukur kinerja keuangan (Z-Score ) :

Z-Score $=0,717 \mathrm{X}_{1}+0,847 \mathrm{X}_{2}+3,107 \mathrm{X}_{3}+$ $0,420 \mathrm{X}_{4}+0,998 \mathrm{X}_{5}$

a. Variabel $\mathrm{X}_{1}, \mathrm{X}_{2}, \mathrm{X}_{3}, \mathrm{X}_{4}$ dan $\mathrm{X}_{5}$ :

$\mathrm{X}_{1}$ : Rasio Modal kerja terhadap Total Aktiva (\%)

$\mathrm{X}_{2}$ : Rasio Laba ditahan terhadap Total Aktiva (\%)
$\mathrm{X}_{3}$ : Rasio Laba bersih Operasi terhadap Total Aktiva(\%)

$\mathrm{X}_{4}$ : Nilai buku modal sendiri terhadap Total Liabilitas (\%)

$\mathrm{X}_{5}$ : Rasio Penjualan terhadapTotal Aktiva (kali)

b. Analisis Z-Score

c. Interpretasi hasil perhitungan dengan asumsi.

d. Jika nilai Z-Score lebih besar dari 2,90 maka perusahaan yang bersangkutan memiliki kinerja keuangan yang sehat.

e. Jika nilai Z-Score di antara 1,23 sampai 2,90 maka kondisi kinerja keuangan perusahaan tersebut masuk zone rawan.

f. Jika nilai Z-Score lebih kecil dari 2,33 maka perusahaan yang bersangkutan terindikasi memiliki kinerja keuangan yang tidak sehat (distress). Dari hasil perhitungan rasio-rasio tersebut akan digunakan untuk menjawab pertanyaan tentang kinerja keuangan perusahaan manufaktur di bidang industri logam yang go public meliputi ZScore setiap sampel dalam setiap tahun pengamatan dan dijelaskan setiap periode.

\section{Sumber Data}

Sumber data berupa laporan keuangan perusahaan yang masih aktif di Bursa Efek Indonesia periode 2012-2016 dan data diperoleh dari Indonesian Capital Market Directory (ICMI) tahun 2012-2016, Fact Book IDX dan website Indonesian Stock Exchange (www.idx.co.id).

\section{Cara Pengumpulan Data}

Dalam penelitian pengumpulan data digunakan metode dokumentasi yaitu membuat salinan dan menggandakan arsip dan catatan dari Bursa Efek Indonesia. Data yang dikumpulkan adalah data sekunder yang diperoleh dari Indonesian Capital Market Directory. Data sekunder merupakan data yang telah diolah menjadi laporan dari sumber aslinya, antara lain:

1. Data mengenai gambaran umum perusahaan atau profil perusahaan.

2. Data laporan keuangan yang menjadi objek penelitian untuk periode 2012-2016, terdiri atas:

a. Neraca Konsolidasi

Neraca konsolidasi merupakan laporan keuangan yang disusun secara sistematis untuk menyajikan posisi keuangan pada suatu periode tertentu.

b. Laporan Laba Rugi Konsolidasi Laporan laba rugi konsolidasi merupakan laporan yang disusun secara sistematis untuk menyajikan hasil usaha 
perusahaan dalam waktu periode tertentu.

\section{Teknik Penentuan Data}

Subyek atau populasi dalam penelitian ini adalah semua perusahaan manufaktur di bidang pabrik logam yang telah terdaftar di Bursa Efek Indonesia untuk periode 2012-2916.

Sampel dalam penelitian ini dilakukan dengan non-probability sampling yaitu teknik sampling yang tidak memberikan kesempatan (peluang) pada setiap populasi untuk dijadikan anggota sample. Dominikus (2013:118) untuk pemilihan sampel menggunakan metode purposive sampling, yaitu pemilihan sampel secara tidak acak yang informasinya diperoleh dengan menggunakan pertimbangan tertentu.

Penentuan data ini didasarkan atas pertimbangan sebagai berikut:

1. Penelitian dilakukan pada semua perusahaan manufaktur bergerak di bidang industri logam/metal yang telah terdaftar di BEI.

2. Perusahaan yang dipilih adalah yang data keuangannya lengkap untuk periode 2011 sampai dengan 2016.

\section{Rancangan Analisis dan Uji Hipotesa}

Dalam analisis data metode yang digunakan adalah Multiple regression analisys (Almant Z-Score) dan analisis korelasi (PPM), dalam metode ini rasio-rasio yang digunakan dikelompokkan ke dalam tiga kelomok besar, yaitu:

a. Rasio Likuiditas : Rasio Modal kerja/Total Aktiva ( $\left.\mathrm{X}_{1}\right)$

b. Rasio Profitabilitas: Rasio Laba ditahan/ Total Aktiva $\left(\mathrm{X}_{2}\right)$

Rasio Laba bersih Operasi/Total Aktiva $\left(\mathrm{X}_{3}\right)$

c. Rasio Aktivitas : Nilai buku modal sendiri /

Total Liabilitas ( $\mathrm{X}_{4}$ )

Rasio Penjualan/Total Aktiva (X)

Langkah-langkah analisis diskriminasi dari Altman Z-Score adalah sebagai berikut:

$\mathrm{Z}$-Score $=0,717 \mathrm{X}_{1}+0,847 \mathrm{X}_{2}+3,107 \mathrm{X}_{3}+$ $0,420 X+0,998 X$

a. Menghitung variabel $X_{1}, X_{2}, X_{3}, X_{4}$ dan $X_{5}$

b. Analisis Z-Score Interpretasi hasil perhitungan dengan asumsi:

c. Jika nilai Z-Score lebih besar dari 2,90 maka perusahaan yang bersangkutan memiliki kinerja keuangan yang sehat.

d. Jika nilai Z-Score di antara 1,23 sampai 2,90 maka kondisi kinerja keuangan perusahaan tersebut masuk zone rawan.

e. Jika nilai Z-Score lebih kecil dari dari 1,22 dan atau 2,33 maka perusahaan yang bersangkutan terindikasi memiliki kinerja keuangan yang tidak sehat (distress).

\section{HASIL PENELITIAN \\ DAN PEMBAHASAN \\ Gambaran Umum Obyek Penelitian}

Sesuai teknik penentuan data, maka pengambilan sampel dilakukan dengan nonprobability sampling dari perusahaan manufaktur industri logam yang telah terdaftar di Bursa Efek Indonesia (BEI), melaporkan laporan keuangan secara konsisten mulai periode 2012 sampai dengan 2016. Diperoleh 15 perusahaan sampel yang selanjutnya digunakan sebagai sumber data untuk analisis.

\section{Pengujian dan Analisis Data}

Menurut Ghozali (2013:19) statistik deskriptif memberikan gambaran atau deskriptif data yang dilihat dari nilai rata-rata (mean), standar deviasi, varian, maksimum, minimum, sum, range, kurtosis dan skewness (kemencengan distribusi).

\begin{tabular}{|l|c|c|c|c|c|c|}
\hline \multicolumn{7}{|c}{ Tabel 1.1. Hasil Uji Statistik Deskriptif } \\
& $\begin{array}{c}\text { WCAT } \\
X_{1}\end{array}$ & $\begin{array}{c}\text { RETA } \\
X_{2}\end{array}$ & $\begin{array}{c}\text { ROI } \\
X_{3}\end{array}$ & $\begin{array}{c}\text { BVETL } \\
X_{4}\end{array}$ & $\begin{array}{c}\text { TATO } \\
X_{5}\end{array}$ & Z-Score \\
\hline Mean & 0.249722 & 0.106611 & 0.046156 & 2.276944 & 1.006389 & 0.006644 \\
\hline Median & 0.200000 & 0.095000 & 0.030000 & 0.610000 & 0.830000 & -0.100000 \\
\hline Maximum & 0.960000 & 0.760000 & 0.650000 & 25.86000 & 3.790000 & 1.160000 \\
\hline Minimum & -0.190000 & -1.960000 & 0.080000 & -0.620000 & 0.150000 & -0.840000 \\
\hline Std. Dev. & 0.259186 & 0.596998 & 0.100016 & 4.068826 & 0.764124 & 0.392542 \\
\hline Skewness & 0.339068 & -1.918233 & 3.452775 & 3.614027 & 1.920544 & 0.866765 \\
\hline Kurtosis & 2.552984 & 7.260236 & 20.41704 & 18.76875 & 6.283961 & 4.030824 \\
\hline $\begin{array}{l}\text { Jarque- } \\
\text { Bera }\end{array}$ & 1.979075 & 98.60422 & 1053.120 & 902.6949 & 76.61508 & 12.20318 \\
\hline Probability & 0.371749 & 0.000000 & 0.000000 & 0.000000 & 0.000000 & 0.002239 \\
\hline Sum & 17.98000 & 7.676000 & 3.323200 & 163.9400 & 72.46000 & 0.478400 \\
\hline $\begin{array}{l}\text { Sum Sq. } \\
\text { Dev }\end{array}$ & 4.769594 & 25.30487 & 0.710221 & 1175.430 & 41.45586 & 10.94036 \\
\hline $\begin{array}{l}\text { Observa- } \\
\text { tions }\end{array}$ & 72 & 72 & 72 & 72 & 72 & 72 \\
\hline & & & & & & \\
\hline
\end{tabular}

Hasil analisis statistik deskriptif di atas sebagai berikut :

Jumlah input data observasi dari jumlah observasi $(\mathrm{n})=75$ dengan jumlah variabel 6 terdiri dari 5 variabel independen dan 1 variabel dependen, dan dari output analisis eviews jumlah data observasi yang diterima berjumlah 72 .

1. Variabel $\mathrm{X}_{1}$ (WCTA):

a. Nilai mean (u) atau rata-rata= 0.249722, menunjukkan variabel WCTA memiliki nilai tengah atau kecenderungan pusat 0.249722

b. Nilai median sebesar $0.200000, \mathrm{me}^{-}$ nunjukkan nilai tengah dari penyebaran data sampel sama dengan 0.200000 . 
c. Nilai maksimum sebesar 0.960000 , nilai ini menunjukkan penyebaran kurva distribusi ke kanan sebesar o.96000o terhadap mean.

d. Nilai minimum sebesar -0.190000, nilai ini menunjukkan penyebaran kurva distribusi ke kiri -0.19000o terhadap mean.

e. Standar deviasi sebesar 0.259186, nilai ini menunjukkan seberapa dekat titik data individu ke mean (rata-rata) nilai sampel. Standar deviasi besar dari nol menunjukkan bahwa semua nilai-nilai dalam himpunan tersebut adalah tidak sama atau memberi makna titik data individu jauh dari nilai rata-rata.

f. Nilai Skewness 0.339068, bernilai positif, maka frekuensi dari kurva distribusi ekornya lebih memanjang ke kanan terhadap mean.

g. Nilai Kurtosis 2.552984, lebih kecil dari 3, menunjukkan kurva lebih datar dari kurva distribusi normal atau disebut platikurti, memberi makna tidak terdapat Jarque-Bera 1.979075 dengan probabilitas 0.371749 lebih besar dari derajat signifikan $(\alpha)=0.05$, menujukan data berdistribusi normal.

2. Variabel $X_{2}$ (RETA):

a. Nilai mean (u) atau rata-rata = o.1066611, menunjukkan variabel RETA memiliki nilai tengah atau kecenderungan pusat $=0.1066611$

b. Nilai median $=0.095000$, menunjukkan nilai tengah dari penyebaran data sampel sama dengan 0.095000 .

c. Nilai maksimum sebesar 0.760000 , nilai ini menunjukkan penyebaran kurva distribusi ke kanan sebesar 0.760000 terhadap mean.

d. Nilai minimum sebesar -1.9600oo, nilai ini menunjukkan penyebaran kurva distribusi ke kiri sebesar -1.960000 terhadap mean.

e. Standar deviasi sebesar 0.596998, nilai ini menunjukkan seberapa dekat titik data individu ke mean (rata-rata) nilai sampel. Standar deviasi besar dari nol menunjukkan bahwa semua nilainilai dalam himpunan tersebut adalah tidak sama atau memberi makna titik data individu jauh dari nilai rata-rata.

f. Nilai Skewness -01.918233, bernilai negatiff, maka frekuensi dari kurva distribusi ekornya lebih memanjang ke kiri terhadap mean

g. Nilai Kurtosis 7.260236, lebih besar dari 3, menunjukkan kurva lebih runcing (tinggi) dari distribusi normal atau disebut leptokurti, memberi makna terdapat data outlier.

h. Jarque-Bera 98.60422 dengan probabilitas 0.0000 lebih kecil dari $\alpha=0.05$, menujukan data tidak berdistribusi normal.

3. Variabel $\mathrm{X}_{3}$ (ROI):

a. Nilai mean (u) atau rata-rata= 0.046156, menunjukkan variabel ROI memiliki nilai tengah atau kecenderungan pusat 0.046156 .

b. Nilai median sebesar 0.030000 , menunjukkan nilai tengah dari penyebaran data sampel sama dengan 0.030000 .

c. Nilai maksimum sebesar 0.650000 , nilai ini menunjukkan penyebaran kurva distribusi ke kanan sebesar 0.650000 terhadap mean.

d. Nilai minimum sebesar -0.08000o, nilai ini menunjukkan penyebaran kurva distribusi ke kiri -0.08000o terhadap mean.

e. Standar deviasi sebesar 0.100016, nilai ini menunjukkan seberapa dekat titik data individu ke mean (rata-rata) nilai sampel. Standar deviasi besar dari nol menunjukkan bahwa semua nilai-nilai dalam himpunan tersebut adalah tidak sama atau memberi makna titik data individu jauh dari nilai rata-rata.

f. Nilai Skewness 3.452775, bernilai positif, maka frekuensi dari kurva distribusi ekornya lebih memanjang ke kanan terhadap mean.

g. Nilai Kurtosis 20.41704, lebih besar dari 3, menunjukkan kurva lebih lancip (tinggi) dari kurva distribusi normal atau disebut leptokurti, memberi makna terdapat data outlier.

h. Jarque-Bera 1053.1205 dengan probabilitas 0.00000 lebih kecil dari $\alpha=0.05$, menujukan data tidak berdistribusi normal.

4. Variabel $\mathrm{X}_{4}$ (BVETL):

a. Nilai mean (u) atau rata-rata= 2.276944, menunjukkan variabel BVETL memiliki nilai tengah atau kecenderungan pusat 2.276944 .

b. Nilai median sebesar 0.610000 , menunjukkan nilai tengah dari penyebaran data sampel sama dengan 0.610000 .

c. Nilai maksimum sebesar 25.86000 , nilai ini menunjukkan penyebaran kurva distribusi ke kanan sebesar 25.8600o terhadap mean. 
d. Nilai minimum sebesar -0.620000, nilai ini menunjukkan penyebaran kurva distribusi ke kiri -0.62000o terhadap mean.

e. Standar deviasi sebesar 4.068826, nilai ini menunjukkan seberapa dekat titik data individu ke mean (rata-rata) nilai sampel. Standar deviasi besar dari nol menunjukkan bahwa semua nilainilai dalam himpunan tersebut adalah tidak sama atau memberi makna titik data individu jauh dari nilai rata-rata.

f. Nilai Skewness 3.614027, bernilai positif, maka frekuensi dari kurva distribusi ekornya lebih memanjang ke kanan terhadap mean.

g. Nilai Kurtosis 18.768754 , lebih besar dari 3, menunjukkan kurva lebih lancip (tinggi) dari kurva distribusi normal atau disebut leptokurti, memberi makna terdapat data outlier.

h. Jarque-Bera 902.6949 dengan probabilitas 0.00000 lebih kecil dari $\alpha=0.05$, menujukan data tidak berdistribusi normal.

5. Variabel $\mathrm{X}_{5}$ (TATO):

a. Nilai mean (u) atau rata-rata= 1.006389, menunjukkan variabel TATO memiliki nilai tengah atau kecenderungan pusat 1.006389 .

e. Nilai median sebesar 0.830000 , menunjukkan nilai tengah dari penyebaran data sampel sama dengan o.830000.

f. Nilai maksimum sebesar 3.79000, nilai ini menunjukkan penyebaran kurva distribusi ke kanan sebesar 3.79000 terhadap mean.

d. Nilai minimum sebesar 0.150000 , nilai ini menunjukkan penyebaran kurva distribusi ke kiri 0.150000 terhadap mean.

e. Standar deviasi sebesar 0.764124, nlai ini menunjukkan seberapa dekat titik data individu ke mean (rata-rata) nilai sampel. Standar deviasi besar dari nol menunjukkan bahwa semua nilai-nilai dalam himpunan tersebut adalah tidak sama atau memberi makna titik data individu jauh dari nilai rata-rata.

f. Nilai Skewness 1.920544, bernilai positif, maka kurva frekuensi dari distribusi ekornya lebih memanjang ke kanan terhadap mean.

g. Nilai Kurtosis 6.283961 lebih besar dari 3, menunjukkan kurva lebih lancip (tinggi) dari kurva distribusi normal atau disebut leptokurti, memberi makna terdapat data outlier.

h. Jarque-Bera 76.61508 dengan probabilitas 0.00000 lebih kecil dari $\alpha=0.05$, menujukan data tidak berdistribusi normal.

6. Variabel Dependen ( Z-score):

a. Nilai mean $(\mathrm{u})$ atau rata-rata= o..006644, menunjukkan variabel dependen (Z-Score) memiliki nilai tengah atau kecendrungan pusat 0.006644 .

b. Nilai median sebesar -0.100000, menunjukkan nilai tengah dari penyebaran data sampel sama dengan -0.100000 .

c. Nilai maksimum sebesar 1.160000 , nilai ini menunjukkan penyebaran kurva distribusi ke kanan sebesar 1.160000 terhadap mean.

d. Nilai minimum sebesar -0.840000 , nilai ini menunjukkan penyebaran kurva distribusi ke kiri -0.84000o terhadap mean.

e. Standar deviasi sebesar 0.392542, nilai ini menunjukkan seberapa dekat titik data individu ke mean (rata-rata) nilai sampel. Standar deviasi besar dari nol menunjukkan bahwa semua nilai-nilai dalam himpunan tersebut adalah tidak sama atau memberi makna titik data individu jauh dari nilai rata-rata.

f. Nilai Skewness 0.866765 , bernilai positif, maka kurva frekuensi dari distribusi ekornya lebih memanjang ke kanan terhadap mean.

g. Nilai Kurtosis 4.030824 lebih besar dari 3, menunjukkan kurva lebih lancip (tinggi) dari kurva distribusi normal atau disebut leptokurti, memberi makna terdapat data outlier.

h. Jarque-Bera 12.20318 dengan probabilitas 0.002239 lebih kecil dari $\alpha=0.05$, menujukan data tidak berdistribusi normal.

\section{Pengujian Asumsi Klasik}

Menurut Ghozali (2013:105) Uji Asumsi Klasik digunakan untuk menguji, apakah model regresi yang digunakan dalam penelitian ini layak diuji atau tidak. Uji Asumsi klasik digunakan untuk memastikan bahwa multikolinearitas, autokorelasi, dan heteroskedastisitas tidak terdapat dalam model yang digunakan dan data yang dihasilkan terdistribusi normal. Jika keseluruhan syarat tersebut terpenuhi, berarti bahwa model analisis layak digunakan. 
JURNAL ILMIAH FEASIBLE: Bisnis, Kewirausahaan \& Koperasi, Vol. 1, No. 1, Februari 2019: 39 - 52

\begin{tabular}{|c|c|c|c|}
\hline \multicolumn{4}{|c|}{ Tabel .1.2. Uji Multiklolinearitas } \\
\hline \multicolumn{4}{|c|}{$\begin{array}{l}\text { Date: } 07 / 28 / 18 \text { Time: } 15: 10 \\
\text { Sample: } 190 \\
\text { Included observations: } 73\end{array}$} \\
\hline Variable & $\begin{array}{l}\text { Coefficient } \\
\text { Variance }\end{array}$ & $\begin{array}{c}\text { Uncentered } \\
\text { VIF }\end{array}$ & $\begin{array}{c}\text { Centered } \\
\text { VIF }\end{array}$ \\
\hline C & 0.169947 & 5.727813 & NA \\
\hline$X_{1}$ & 1.908373 & 8.302904 & 3.012389 \\
\hline $\mathrm{X}_{2}$ & 0.211867 & 2.488353 & 1.500624 \\
\hline $\mathrm{X}_{3}$ & 3.957138 & 1.546211 & 1.037235 \\
\hline$X_{4}$ & 0.019164 & 4.156969 & 2.449808 \\
\hline$X_{5}$ & 0.037397 & 2.672465 & 1.177899 \\
\hline
\end{tabular}

Hasil Uji Multiklolinearitas dari tabel 4.3, semua ke 5 variabel Independen memiliki VIF $<$ 10, maka menujukan tidak terdapat multikolinieritas dari kelima variabel independen.

Dengan perhitungan, dilakukan dengan membandingkan $\mathrm{F}_{\text {hitung }}$ dengan $\mathrm{F}_{\text {tabel }}$, sebagai dasar penilaian:

$\mathrm{H}_{0}$ : pada $\alpha=0.05$, bila $\mathrm{F}_{\text {hitung }}<\mathrm{F}_{\text {tabel }}$ maka terdapat multikolinieritas yaitu adanya hubungan linier antar variabel independen.

$\mathrm{H}_{\mathrm{a}}$ : pada $\alpha=0.05$, bila $\mathrm{F}_{\text {hitung }}>\mathrm{F}_{\text {tabel }}$ maka tidak terdapat multikolinieritas yaitu tidak adanya hubungan linier antar variabel independen.

\begin{tabular}{|c|c|c|c|c|}
\hline \multicolumn{5}{|c|}{ Tabel 1.3. Uji multikolinieritas dan Uji Hipotesis } \\
\hline \multicolumn{5}{|c|}{ Dependent Variable: $Y$} \\
\hline \multicolumn{5}{|c|}{$\begin{array}{l}\text { Dependent Variable: } Y \\
\text { Method: Panel Least Squares } \\
\text { Date: } 07 / 28 / 18 \text { Time: } 19: 49 \\
\text { Sample: } 2011 \text { 2015 } \\
\text { Periods included: } 5 \\
\text { Cross-sections included: } 15 \\
\text { Total panel (unbalanced) observations: } 73\end{array}$} \\
\hline Variable & Coefficient & Std. Error & t-Statistic & Prob. \\
\hline c & -0.111699 & 0.097779 & -1.142359 & 0.2574 \\
\hline$x_{1}$ & 0.231958 & 0.204777 & 1.132738 & 0.2614 \\
\hline $\mathrm{X}_{2}$ & 0.023943 & 0.086116 & 0.278031 & 0.7818 \\
\hline$X_{3}$ & 1.541056 & 0.485957 & 3.171177 & 0.0023 \\
\hline$X_{4}$ & -0.020641 & 0.013555 & -1.522742 & 0.1325 \\
\hline$X_{5}$ & 0.027384 & 0.059974 & 0.456604 & 0.6494 \\
\hline \multicolumn{2}{|l|}{ R-squared } & \multicolumn{2}{|c|}{ Mean dependent var } & 0.002033 \\
\hline Adjusted R-squared & 0.136271 & \multicolumn{2}{|c|}{ S.D. dependent var } & 0.391793 \\
\hline S.E. of regression & 0.368521 & \multicolumn{2}{|c|}{ Akaike info criterion } & 0.919977 \\
\hline Sum squared resid & 9.099103 & \multicolumn{2}{|c|}{ Schwarz criterion } & 1.108234 \\
\hline Log likelihood & -27.57916 & \multicolumn{2}{|c|}{ Hannan-Quinn criter. } & 0.995001 \\
\hline F-statistic & 2.876177 & \multicolumn{2}{|c|}{ Durbin-Watson stat } & 1.1 .730270 \\
\hline Prob(F-statistic) & 0.020620 & & & \\
\hline
\end{tabular}

Dari tabel 1.3 diperoleh $\mathrm{F}_{\text {hitung }} 2.876>\mathrm{F}_{\text {tabel }}$
2.73 dengan probabilitas $0.0206<\alpha=0.05$, menunjukkan tidak terdapat multikolinieritas yaitu tidak adanya hubungan linier antar variabel independen.

\begin{tabular}{|c|c|}
\hline \multicolumn{2}{|c|}{ Tabel 1.4. UJI Durbin-Watson Autokorelasi } \\
\hline $0-1$ & Ada autokorelasi \\
\hline $1.1-1.54$ & Tanpa kesimpulan \\
\hline $1.55-2.46$ & Tidak ada autokorelasi \\
\hline $2.46-2.9$ & Tanpa kesimpulan \\
\hline $2.9-4.0$ & Ada autokorelasi \\
\hline \multicolumn{2}{|c}{} \\
\hline
\end{tabular}

Dari analisis yang dilakukan diperoleh nilai Durbin-Waston sebesar 1,730270, berdasarkan tabel 4.4 bila nilai 1,730270 di antara $1,55-$ 2,46 menunjukkan tidak ada autokorelasi.

\begin{tabular}{|c|c|c|c|c|}
\hline \multirow{2}{*}{\multicolumn{5}{|c|}{$\begin{array}{c}\text { Tabel 1.5. Uji Heteroskedastis } \\
\text { Heteroskedasticity Test: White }\end{array}$}} \\
\hline & & & & \\
\hline F-statistic & 1.114712 & \multicolumn{2}{|c|}{ Prob. F(20,52) } & 0.3641 \\
\hline Obs*R-squared & 21.90586 & \multicolumn{2}{|c|}{ Prob. Chi-Square(20) } & 0.3456 \\
\hline \multicolumn{2}{|l|}{ Scaled explained SS } & \multicolumn{2}{|c|}{ Prob. Chi-Square(20) } & 0.0089 \\
\hline \multicolumn{5}{|c|}{$\begin{array}{l}\text { Test Equation: } \\
\text { Dependent Variable: RESID^2 } \\
\text { Method: Least Squares } \\
\text { Date: 07/28/18 Time: } 20: 00 \\
\text { Sample: } 175 \\
\text { Included observations: } 73\end{array}$} \\
\hline Variable & Coefficient & Std. Error & t-Statistic & Prob. \\
\hline $\mathrm{C}$ & 0.242650 & 0.209005 & 1.160976 & 0.2510 \\
\hline $\mathrm{X} 1$ & -1.518075 & 0.559384 & -2.713832 & 0.0090 \\
\hline $\mathrm{X} 1^{\wedge} 2$ & 0.992014 & 1.259495 & 0.787629 & 0.4345 \\
\hline $\mathrm{X} 1 * \mathrm{X} 2$ & 2.487112 & 1.075664 & 2.312165 & 0.0248 \\
\hline $\mathrm{X} 1{ }^{*} \times 3$ & -2.655696 & 3.596702 & -0.738370 & 0.4636 \\
\hline$X 1^{*} X 4$ & -0.320908 & 0.310965 & -1.031974 & 0.3069 \\
\hline$X 1 * X 5$ & 0.657860 & 0.305105 & 2.156173 & 0.0357 \\
\hline $\mathrm{X} 2$ & -1.296600 & 0.575314 & -2.253727 & 0.0285 \\
\hline$X 2^{\wedge} 2$ & -0.245320 & 0.289649 & -0.846955 & 0.4009 \\
\hline $\mathrm{X} 2{ }^{*} \times 3$ & -0.486917 & 2.615740 & -0.186149 & 0.8531 \\
\hline$X 2^{*} \times 4$ & 0.199381 & 0.174872 & 1.140153 & 0.2594 \\
\hline $\mathrm{X} 2 * \times 5$ & 0.058633 & 0.320892 & 0.182718 & 0.8557 \\
\hline $\mathrm{X} 3$ & 3.829899 & 1.964056 & 1.949995 & 0.0566 \\
\hline$x 3^{\wedge} 2$ & -8.197963 & 4.944747 & -1.657914 & 0.1034 \\
\hline$X 3^{*} \times 4$ & 0.154028 & 0.271325 & 0.567690 & 0.5727 \\
\hline$X 3^{*} \times 5$ & 0.077009 & 1.809002 & 0.042570 & 0.9662 \\
\hline$X 4$ & 0.095613 & 0.137743 & 0.694142 & 0.4907 \\
\hline$X 4^{\wedge} 2$ & -0.001268 & 0.002995 & -0.423445 & 0.6737 \\
\hline$X 4^{*} \times 5$ & -0.049142 & 0.070295 & -0.699074 & 0.4876 \\
\hline $\mathrm{X} 5$ & 0.050184 & 0.258355 & 0.194244 & 0.8467 \\
\hline$x 5^{\wedge} 2$ & -0.061355 & 0.067472 & -0.909352 & 0.3674 \\
\hline R-squared & 0.300080 & Mean deper & dent var & 0.124645 \\
\hline Adjusted R-squared & 0.030880 & S.D. depend & ent var & 0.254605 \\
\hline S.E. of regression & 0.250643 & Akaike info & riterion & 0.306553 \\
\hline Sum squared resid & 3.266741 & Schwarz crit & erion & 0.965452 \\
\hline
\end{tabular}


JURNAL ILMIAH FEASIBLE: Bisnis, Kewirausahaan \& Koperasi, Vol. 1, No. 1, Februari 2019: 39 - 52

\begin{tabular}{|ll|ll|}
\hline Log likelihood & 9.810818 & Hannan-Quinn criter. & 0.569136 \\
\hline F-statistic & 1.114712 & Durbin-Watson stat & 2.038045 \\
\hline Prob(F-statistic) & 0.364194 & \\
\hline \multicolumn{4}{|l}{ Sumber : Data diolah dengan menggunakan Eviews7 } \\
\hline
\end{tabular}
berikut:

Menurut Winarno (2015:5.17), sebagai

$\mathrm{H}_{\mathrm{o}}$ : Nilai Obs* ${ }^{*}$-Squared dengan nilai probabilitas $>\alpha=0,05$ maka dapat disimpulkan bahwa data tersebut tidak bersifat heteroskedatis

$\mathrm{H}_{\mathrm{a}}$ : Nilai Obs*${ }^{*} \mathrm{R}-$ Squared dan Nilai Probabilitas $<\alpha=0,05$ maka dapat disimpulkan bahwa data tersebut bersifat heteroskedatis

Dari data analisis nilai Obs* ${ }^{*}$-Squared $=$ 21,90586 dengan nilai probabilitas 0,3456 > $\alpha=0,05$ maka dapat disimpulkan bahwa data tersebut tidak bersifat heteroskedatis.

\section{Uji Hipotesis}

Dari Tabel 1.3., Uji Kecocokan model (Goodness of Fit), koefisien determinasi $\left(\mathrm{R}^{2}\right)$ pada intinya mengukur seberapa jauh kemampuan model dalam menerangkan variasi variabel independen Dalam penelitian ini digunakan lebih dari dua variabel bebas, maka digunakan $\mathrm{R}^{2}$ yang disesuaikan sebagai koefisien determinasi dari kolom Adjusted $\mathrm{R}$ square $\left(\mathrm{R}^{-2}\right)$ pada output Eviews diperoleh angka sebagai berikut :

Dari tabel di atas Adjusted R-squared bernilai 0,1363 atau $13,63 \%$ berarti variabilitas Z-score (Y) dapat dijelaskan oleh kelima varibel independen WCTA, RETA, ROI, BVETL dan TATO sekitar $13,63 \%$ dan sisanya $86,37 \%$ merupakan pengaruh variabel lain diluar model ini.

Model persamaan regresi linear berganda berdasarkan hasil analisis adalah :

$$
\begin{aligned}
Y: & -0,111699+0,231958 X_{1}+0,023943 X_{2} \\
& +1,541056 X_{3}-0,020641 X_{4}+0,027384 \\
& X_{5} .
\end{aligned}
$$

Interpretasi dari persamaan regresi linear berganda berdasarkan hasil di atas adalah :

a. Nilai konstanta pada tabel adalah $\mathrm{C}=$ -0,111699 dibulatkan -0,112. artinya jika $\mathrm{X}_{1}, \mathrm{X}_{2}, \mathrm{X}_{3}, \mathrm{X}_{4}$ dan $\mathrm{X}_{5}$ bernilai nol, maka nilai harga saham akan turun sebesar -0,112 terhadap satuan Z-Score.

b. Koefisien regresi $X_{1}$ pada pengujian tersebut sebesar 0,231958 (dibulatkan 0,232 ) artinya $X$ memiliki pengaruh positif terhadap Z-Score dimana bila $\mathrm{X}$ mengalami kenaikan sebesar 1\% maka Z-Score akan naik sebesar 0,232 \% dengan asumsi variabel-variabel lain tidak berubah.

c. Koefisien regresi $\mathrm{X}_{2}$ pada pengujian ter- sebut sebesar 0,023943 (dibulatkan o,024) artinya $X_{2}$ memiliki pengaruh positif terhadap Z-Score dimana bila $\mathrm{X}_{2}$ mengalami kenaikan sebesar $1 \%$ maka Z-Score akan naik sebesar 0,024\% dengan asumsi variabel-variabel lain tidak berubah.

d. Koefisien regresi $\mathrm{X}_{3}$ pada pengujian tersebut sebesar 1,541056 (dibultakan 1,541) artinya $\mathrm{X}_{2}$ memiliki pengaruh positif terhadap Z-Score dimana bila $\mathrm{X}_{3}$ mengalami kenaikan sebesar $1 \%$ maka Z-Score akan naik sebesar $1,541 \%$ dengan asumsi variabel-variabel lain tidak berubah.

e. Koefisien regresi $\mathrm{X}_{4}$ pada pengujiantersebut sebesar -0,020641 (dibulatkan -0,021) artinya $X_{4}$ memiliki pengaruh negatif terhadap Z-Scorea bila $\mathrm{X}$ mengalami kenaikan sebesar 1\% maka Z-Score akan turun sebesar -0,021\% dengan asumsi variabel-variabel lain tidak berubah.

f. Koefisien regresi $X_{5}$ pada pengujian tersebut sebesar 0,027384 (dibulatkan 0,027) artinya $\mathrm{X}_{5}$ memiliki pengaruh positif terhadap Z-sore dimana bila $\mathrm{X}_{5}$ mengalami kenaikan sebesar $1 \%$ maka Z-Score akan naik sebesar 0,027\% dengan asumsi variabel-variabel lain tidak berubah.

\begin{tabular}{|c|c|l|}
\hline \multicolumn{3}{|c|}{ Tabel 1.6. Hasil Analisis regresi berganda } \\
\hline Variabel & Koefisien Regresi & \multicolumn{1}{c|}{$\begin{array}{c}\text { Keterangan } \\
\text { (Pengaruhnya terhadap Z-Score) }\end{array}$} \\
\hline C (Konstanta) & $-0,111699(-0,112)$ & $\begin{array}{l}\text { Untuk } \mathrm{X}_{1}, \ldots, \mathrm{X}_{5} \text { bernilai tetap tau nol, } \\
\text { maka harga saham akan turun sebesar } \\
-0,112 \text { terhadap satuan Z-Score. }\end{array}$ \\
\hline $\mathrm{X}_{1}$ (WCTA) & $0,231958(0,232)$ & $\begin{array}{l}\text { Bila } \mathrm{X}_{1} \text { naik } 1 \% \text { maka Z-score akan naik } \\
0,232 \%, \text { varaibel lain dianggap tetap. }\end{array}$ \\
\hline $\mathrm{X}_{2}$ (RETA) & $0,023943(0,024)$ & $\begin{array}{l}\text { Bila } \mathrm{X}_{2} \text { naik } 1 \% \text { maka Z-Score akan naik } \\
0,024 \%, \text { variabel lain dianggap tetap. }\end{array}$ \\
\hline $\mathrm{X}_{3}$ (ROI) & $1,541056(1,541)$ & $\begin{array}{l}\text { Bila } \mathrm{X}_{3} \text { naik } 1 \% \text { maka Z-Score akan naik } \\
1,541 \%, \text { variabel lain dianggap tetap. }\end{array}$ \\
\hline $\mathrm{X}_{4}$ (BVETL) & $-0,020641(-0,021)$ & $\begin{array}{l}\text { Bila } \mathrm{X}_{4} \text { naik } 1 \% \text { maka Z-Score akan } \\
\text { turun }-0,021 \% \text {, variabel lain dianggap } \\
\text { tetap. }\end{array}$ \\
\hline$X_{5}$ (TATO) & $0,027384(0,027)$ & $\begin{array}{l}\text { Bila } \mathrm{X}_{5} \text { naik } 1 \% \text { maka Z-Score akan naik } \\
0,027 \%, \text { variabel lain dianggap tetap }\end{array}$ \\
\hline
\end{tabular}

\section{Uji- t (Uji-Parsial ) (Data pada Tabel 3)}

Uji t (uji secara parsial) digunakan untuk menunjukkan apakah variabel independen secara individu mempunyai pengaruh yang signifikan terhadap variabel dependen,

Dasar pengambilan keputusan :

a. Pada derajat signifikan 0,05 di mana $t_{\text {hitung }}$ $>\mathrm{t}_{\text {tabel }}$ maka $\mathrm{H}_{\mathrm{o}}$ untuk $\mathrm{t}_{\text {hitung }}$ diterima.

b. Pada derajat signifikan di mana $0,05 \mathrm{t}$ hitung $<\mathrm{t}_{\text {tabel }}$ dan $\mathrm{F}_{\text {hitung }}<\mathrm{F}_{\text {tabel }}$ maka $\mathrm{H}_{\mathrm{a}}$ untuk $\mathrm{t}_{\text {hitung }}$ dan $\mathrm{F}_{\text {hitung }}$ diterima.

c. $t_{\text {tabel }}$ untuk derajat kemiringan $(\alpha)=0,05$, dan $\mathrm{df}=\mathrm{n}-1=75-1=74$, diperoleh $\mathrm{t}_{\text {tabel }}=$ $1,99495=1,995$ 


\section{Uji-t (Uji-Partial)}

1. Hipotesis Pertama

$\mathrm{H}_{01}$ : Diduga terdapat pengaruh WCTA terhadap Z-Score.

$\mathrm{H}_{\text {оа }}$ : Diduga tidak terdapat pengaruh WCTA terhadap Z-Score.

Untuk WCTA $\mathrm{t}_{\text {hitung }} 1,37238<\mathrm{t}_{\text {tabel }} 1,995$, maka $\mathrm{H}_{\mathrm{a} 1}$ yang diterima, artinya WCTA tidak berpengaruh secara signifikan terhadap Z-Score .

2. Hipotesis kedua

$\mathrm{H}_{02}$ : Diduga terdapat pengaruh RETA terhadap Z-Score.

$\mathrm{H}_{\mathrm{a} 2}$ : Diduga tidak terdapat pengaruh RETA terhadap Z-Score.

RETA memiliki $t_{\text {hitung }} 0,278031<t_{\text {tabel }}$ 1,995 , maka $\mathrm{H}_{\mathrm{a}}$ yang diterima, artinya RETA tidak berpengaruh secara signifikan terhadap Z-Score.

3. Hipotesis ketiga

$\mathrm{H}_{\text {о3 }}$ : Diduga terdapat pengaruh ROI terhadap Z-Score.

$\mathrm{H}_{\text {a3 }}$ : Diduga tidak terdapat pengaruh ROI terhadap Z-Score.

ROI memiliki $\mathrm{t}_{\text {hitung }} 3,171177>\mathrm{t}_{\text {tabel }} 1,95$, dengan probabilitas $0,0023<$ derajat signifikan 0,05 , maka $\mathrm{H}_{03}$ yang diterima, artinya ROI berpengaruh secara sangat signifikan terhadap Z-Score.

4. Hipotesis keempat

$\mathrm{H}_{04}$ : Diduga terdapat pengaruh BVETL terhadap Z-Score.

$\mathrm{H}_{\mathrm{a4}}$ : Diduga tidak terdapat pengaruh BVETL terhadap Z-Score.

BVETL memiliki $\mathrm{t}_{\text {hitung }}-1,522742<\mathrm{t}_{\text {tabel }}$ 1,995, maka $\mathrm{H}_{\mathrm{a4}}$ yang diterima, artinya BVTL tidak berpengaruh secara signifikan terhadap Z-Score.

5. Hipotesis kelima

$\mathrm{H}_{05}$ : Diduga terdapat pengaruh TATO terhadap Z-Score.

$\mathrm{H}_{\mathrm{a} 5}$ : Diduga tidak terdapat pengaruh TATO terhadap Z-Score.

TATO memiliki $t_{\text {hityng }} 0,456604<\mathrm{t}_{\text {tabel }}$ 1,995, maka $\mathrm{H}_{25}$ yang diterima, artinya TATO tidak berpengaruh signifikan terhadap Z-Score.

6. Hipotesis keenam

$\mathrm{H}_{06}$ : Diduga secara bersama-sama WCTA, RETA, ROI, BVETL dan TATO berpengaruh terhadap Z-Score.

$\mathrm{H}_{\mathrm{a}}$ : Diduga secara bersama-sama WCTA, RETA, ROI, BVETL dan TATO tidak berpengaruh terhadap Z-Score.

Dari uji-F diperoleh $\mathrm{F}_{\text {hitung }}$ 2,876177 > $\mathrm{F}_{\text {tabe }}$ 2,74 dengan probabilitas 0,020620 $<$ derajat signifikan 0,05 maka dapat disimpulkan secara bersama-sama variabel independen (WCTA, RETA, ROI, BVETL, TATO) berpengaruh signifikan terhadap Z-Score.

\section{Uji-F ( Uji-Simultan)}

Uji F ( uji-Simultan ) digunakan untuk menunjukkan apakah variabel independen secara bersama-sama mempunyai pengaruh yang signifikan terhadap variabel dependen.

Dasar pengambilan keputusan:

a. Pada derajat signifikan 0,05 di mana $\mathrm{F}_{\text {hitung }}$ $>\mathrm{F}_{\text {tabel }}$ maka $\mathrm{H}_{\mathrm{o}}$ untuk $\mathrm{F}_{\text {hitung }}$ diterima.

b. Pada derajat signifikan di mana $0,05 \mathrm{~F}_{\text {hitung }}$ $<\mathrm{F}_{\text {tabel }}$ maka $\mathrm{H}_{\mathrm{a}}$ untuk $\mathrm{F}_{\text {hitung }}$ diterima.

c. $\mathrm{F}_{\text {tabel }}$ untuk derajat kemiringan $(\alpha)=0,05$, dan $\mathrm{df}=(\mathrm{n}-$ jumlah variabel -1$)=75^{-} 5^{-}$ $1=69$, diperoleh $\mathrm{F}_{\text {tabel }}=2,74$.

\section{Uji-F (Uji-Simultan)}

Uji F (uji-Simultan) digunakan untuk menunjukkan apakah variabel independen secara bersama-sama mempunyai pengaruh yang signifikan terhadap variabel dependen.

Dasar pengambilan keputusan:

d. Pada derajat signifikan 0,05 di mana $\mathrm{F}_{\text {hitung }}$ $>\mathrm{F}_{\text {tabel }}$ maka $\mathrm{H}_{\mathrm{o}}$ untuk F-hitung diterima.

e. Pada derajat signifikan di mana 0,05 $\mathrm{F}_{\text {hitung }}$ $<\mathrm{F}_{\text {tabel }}$ maka Ha untuk $\mathrm{F}_{\text {hitung }}$ diterima.

f. $F_{\text {tabel }}$ untuk derajat kemiringan $(\alpha)=0,05$, dan $\mathrm{df}=(\mathrm{n}-$ jumlah variabel -1$)=75^{-} 5^{-}$ $1=69$, diperoleh $\mathrm{F}_{\text {tabel }}=2,74$.

Hasil Perhitungan Rasio keuangan terhadap Kinerja Perusahaan

$Z: 0,717 \mathrm{X}_{1}+0,874 \mathrm{X}_{2}+3,107 \mathrm{X}_{3}+0,420 \mathrm{X}_{4}+$ $0,988 \mathrm{X}_{5}$

Dengan zona diskriminan (Nilai Cut Off) sebagai berikut:

- $\mathrm{Z}>2,90$ = zone aman

- $\mathrm{Z}$ diantara $1,23-2,9$ atau $1,23<\mathrm{Z}>2,90=$ Zone rawan

- $\mathrm{Z}<1,23$ = zone tidak aman (distress).

a) Dari hasil perhitungan menggunakan Altman Z-Score dari 15 perusahan yang diambil sebagai sampel diprediksi hampir sebagian besar menunjukkan kondisi perusahan cukup mengalami kinerja yang buruk akibat kondisi ekonomi yang tidak konduktif dan tidak ada kepastian.

b) Dengan perincian sebagai berikut:

c) Yang mengalami distress sebanyak empat perusahaan atau $27 \%$, yang mengalami rawan distress tujuh perusahan atau $46 \%$ dan yang masih memiliki kinerja yang baik empat perusahan atau $27 \%$

\section{Analisis Korelasi}

Rumus Analisis korelasi untuk menguji tingkat hubungan antar masing-masing rasio 
keuangan pengaruhnya terhadap kinerja keuangan. Model dalam penelitian ini, Sugiyono (2014:241) adalah:

$$
r_{x y}=\frac{n\left(\sum X_{i} Y_{i}\right)-\left(\sum X_{i}\right)\left(\sum Y_{i}\right)}{\sqrt{\ln n}\left(\sum X_{i}^{2}\right)-\left(\sum X_{i}\right)^{2} \text { 回回 } n \cdot \sum y_{i}^{2}-\left(\sum Y_{i}\right)^{2}}
$$

Di mana:

$\mathrm{Y}_{\mathrm{i}}=\mathrm{Z}$-Score (Kinerja Perusahaan), Rasio Keuangan: $\mathrm{Xi}=\mathrm{X} 1, \mathrm{X}_{2}, \mathrm{X}_{3}, \mathrm{X}_{4}$ dan $\mathrm{X}_{5}$. $\mathrm{r}_{\mathrm{xy}}=$ Koefisien korelasi.

\begin{tabular}{|c|c|c|c|c|c|c|c|}
\hline \multicolumn{8}{|c|}{$\begin{array}{l}\text { Tabel 1.7. Hasil Perhitungan Pengaruh Rasio } X_{i} \text { terhadap } \\
\text { Kinerja Perusahaan (Koefisien Korelasi) }\end{array}$} \\
\hline RASIO & $\mathrm{n}$ & $\sum X_{n}$ & $\sum X_{n} Y$ & $\sum X_{n}^{2}$ & $\Sigma Y$ & $\Sigma \mathrm{Y}^{2}$ & $r_{x y}$ \\
\hline WCTA & 75 & 18,75 & 64,87 & 9,69 & 182,06 & 824.92 & 0,44 \\
\hline RETA & 75 & 7,71 & 81,60 & 26,14 & 182,06 & 824.92 & 0,64 \\
\hline ROI & 75 & 3,00 & 1,06 & 0,87 & 182,06 & 824.92 & 0,51 \\
\hline BVETL & 75 & 166,00 & 1,70 & 1550,22 & 182,06 & 824.92 & T.T \\
\hline TATO & 75 & 82,00 & 1,41 & 159,02 & 182,06 & 824.92 & 0,06 \\
\hline
\end{tabular}

T.T: Tidak Terdifinisikan.

Table 1.8. Pedoman Untuk Memberikan Interpretasi Koefisien Korelasi $\left(r_{x y}\right)$

\begin{tabular}{|c|c|}
\hline Interval Koefisien & Tingkat Hubungan \\
\hline $0,00-0,199$ & Sangat rendah \\
\hline $0,20-0,399$ & Rendah \\
\hline $0,40-0,599$ & Sedang \\
\hline $0,60-0,799$ & Kuat \\
\hline $0,80-1,00$ & Sangat Kuat \\
\hline & Sumber: Sugiyono (2014:242) \\
\hline
\end{tabular}

\begin{tabular}{|l|c|l|}
\hline \multicolumn{3}{|c|}{ Tabel 1.9. Hasil Analisis Korelasi PPM } \\
\multicolumn{1}{|c|}{ Variabel } & $\begin{array}{c}\text { Koefisien Korelasi } \\
(\boldsymbol{r})\end{array}$ & \multicolumn{1}{c|}{$\begin{array}{c}\text { Keterangan } \\
\text { (Pengaruh terhadap Kinerja) }\end{array}$} \\
\hline $\mathrm{X}_{1}$ (WCTA) & 0,44 & $0,4<r<0,599$, pengaruhnya sedang. \\
\hline $\mathrm{X}_{2}$ (RETA) & 0,64 & $0,6<r<0,799$, pengaruhnya kuat. \\
\hline $\mathrm{X}_{3}(\mathrm{ROI})$ & 0,51 & $0,4<r<0,599$, pengaruhnya sedang. \\
\hline $\mathrm{X}_{4}$ (BVETL) & Tidak terdifinisikan & - \\
\hline $\mathrm{X}_{5}$ (TATO) & 0,06 & $0<r<0,199$, pengaruhnya sangat rendah. \\
\hline \multicolumn{3}{|r}{ Sumber: Sugiyono (2015:242) } \\
\hline
\end{tabular}

Dari hasil perhitungan koefisien korelasi (r) untuk kinerja perusahan WCTA dan ROI pengaruhnya sedang, sedangkan RETA pengaruhnya kuat. Menurut Masrun dalam Sugiyono (2001:106) menyatakan bahwa biasanya syarat minimum untuk dianggap valid adalah $\mathrm{r}=0,3$. Untuk BVETL tidak terdefinisikan. TATO sangat rendah pengaruhnya.

\section{SIMPULAN}

\section{Kesimpulan}

Berdasarkan hasil analisis data dan pembahasan yang telah dilakukan, dapat disimpulkan sebagai berikut.

Kinerja keuangan perusahaan manufaktur industri logam yang terdaftar di Bursa Efek Indonesia periode 2012-2016, yang telah diukur dengan alat ukur rasio keuangan (WCTA, RETA, ROI, BVETL dan TATO) yang menggunakan Altman Z-Score diprediksi 73\% mengalami kesulitan keuangan akibat kondisi ekonomi yang tidak konduktif, inflasi yang tinggi dan tidak ada kepastian untuk berinvestasi.

\section{Saran}

Dalam penelitian ini masih perlu dilakukan penyempurnaan agar diperoleh hasil yang lebih valid, yaitu dengan melakukan:

a. Rentang waktu penelitian lebih panjang lagi agar diperoleh data atau sampel yang lebih banyak dan representatif.

b. Menambah jumlah sampel, agar hasil dari analisis dapat mewakili kondisi perusahaan manufaktur yang ada di Indonesia, khususnya yang terdaftar di Bursa Efek Indonesia.

\section{DAFTAR PUSTAKA}

Arikunto Suharsimi. 2013. Prosedur Penelitian Suatu Pendekatan Praktik. Penerbit Rineka Cipa, Jakarta.

Brigham,Houston. 2014. Dasar-Dasar Manajemen Keuangan Essentials of Financial Management. Penerbit Salemba Empat, Jakarta.

Denny Tewu ML. 2013. Meningkatkan Kinerja Keuangan Perusahaan Daerah Dengan Memanfaatkan Pasar Modal Dalam Rangka Menjadikan Indonesia Raksasa Ekonomi Baru. Penerbit Yayasan Taman Pustaka, Jakarta.

Dominikus D. Unaradjan. 2013. Metode Penelitian Kuantitatif. Penerbit Universitas Atma Jaya, Jakarta.

Erich A. Helfert. 2010. Dasar-Dasar Managemen Keuangan. Edisi 11, Binarupa Aksara, Tangerang, 15418.

Fahmi, Irham. 2011. Analisa Laporan Keuangan, Edisi 1. Penerbit ALFABETA, Bandung

Ghozali, Imam. 2013. Aplikasi Analisis Multivariate dengan Program SPSS. Semarang : Badan penerbit UNDIP.

Halim. Abdul. 2015. Akuntansi Keuangan Lanjutan. Penerbit Mitra Wacana Media, Jakarta

Harahap S.S. 2015. Analisis Kritis atas Laporan Keuangan. Divisi Buku Perguruan Tinggi- 
PT.Raja Grafindo Persada, Jakarta.

Hanafi, Mamduh M, Abdul Halim. 2014. Analisa Laporan Keuangan, Edisi 4. UPP STIM YKPN, Yogyakarta.

Hasibuan, Malayu SP. 2014. Manajemen: Dasar, Pengertian dan Masalah, Edisi Revisi. Bumi Aksara, Jakarta.

Joven Suganto Liauw, Trisnadi Wijaya, 2011. Analisis Pengaruh Tingkat Inflasi, Tingkat Suku Bunga SBI dan Nilai Tukar Rupiah Terhadap Indeks Harga Saham Gabungan (IHSG) di BEI.

Kamaludin. 2011. Manajemen Keuangan Konsep Dasar dan Penerapannya. Cetakan ke-7, CV.Mandar Maju, Bandung

Kasmir. 2015. Analisis Laporan Keuangan. Penerbit PT. RAJAGRAFINDO PERSADA, DEPOK.

Manahan P. Tampubolon. 2013. Manajemen Keuangan (Finance Management), Mitra Wacana Media, Jakarta

Moh. Nazir. 2008. Metode Analisis Penelitian Kuantitatif dan Kualitatif. Penerbit Erlangga, Jakarta.

Purnomo Yusgiantoro. 2004. Manajemen Keuangan Internasional Teori dan Praktik. Penerbit Fakultas Ekonomi Universitas Indonesia

Rendra Y. Aditya dan Suwitho. 2014. Pengaruh Kinerja Keuangan Terhadap Harga Saham Pada Perusahaan Rokok Di BEI. Dalam Jurnal Ilmu \& Riset Manajemen Vol.3, No.5.

Robbin \& Coulter. 2010. Manajemen, Edisi Kesepuluh, Jilid 1\&2, Penerbit Erlangga, Jakarta.

Sugiyono. 2014. Metode Penelitian Kombinasi (Mixed Methods). Penerbit ALFABETA, Bandung.

Suharsimi Arikunto. 2013. Prosedur Penelitian Suatu Pendekatan Praktik. Penerbit Rineka Cipta, Jakarta.

Tiara Rachman Putri. 2011. Analisis Pengaruh Kinerja Keuangan Terhadap Harga Saham Pada Perusahaan Manufaktur di Bursa Efek Indonesia.

Wahyudiono B. 2014. Laporan Keuangan. Penerbit Raih Asa Sukses, Jakarta.

Weston \& Copeland. 2010. Manajemen Keuangan. Edisi Revisi, Jilid 1\&2. Penerbit BINARUPA AKSARA, Tangerang.

Widarjono Agus. 2015. Analisis Multivariat Terapan Dengan Program SPSS, AMOS dan SMARTPLS. Penerbit dan Pencetak: UPP STIM YKPN, Yogyakarta 55581.

Winarno W.W. 2015. Analisis Ekonometrika dan Statistika dengan Eviews, Edisi 4. UPP STIM YKPN, Yogyakarta 55581. 